\title{
Indigenous Pottery Technology of Central Mexico during Early Colonial Times
}

\author{
Gilda Hernández Sánchez
}

The Spanish colonization dramatically interrupted the autonomous development of ancient Mesoamerican culture. Nevertheless, indigenous societies learned to live with the conquest. It was not only a time of crisis, but also an extraordinary creative period. The complex interaction between the indigenous and European worlds gave way to new social systems, technologies and artistic expressions. In this process, material culture played a central role. Things provoked rather than just reflected people's particular responses and adaptations to the changing circumstances. After the Spanish conquest, for example, the encounter of Mesoamerican potters with European ceramics profoundly impacted the native pottery technology. Potters faced foreign ceramics and decided to adopt, reinterpret or reject them. This work presents insights into that process of transformation by focusing on the interaction of indigenous potters with the Spanish pottery in central Mexico during the early colonial period ( $A D$ 1521-1650). In that region, on the eve of the conquest, potters made a wide variety of objects, with many techniques and in many styles, in which dexterity, creativity and aesthetics played important roles. The Spaniards introduced new wares and new technologies to produce them. Emblematic were the potter's wheel, the glazing and the majolica ware. They were typical of the Spanish pottery technology at that time and implied a different understanding of ceramics. As will be shown, potters interacted with these novelties in different and complex ways. The pre-Hispanic ceramic technology persisted after the conquest, but the various dimensions of ceramic-making were differently impacted by such particular encounters. Clay recipes, method of forming and firing technology were maintained without change. In contrast, surface finishing and decoration evidenced great creativity.

At the time of the Spanish arrival, the central Mexican ceramic industry was flourishing. Late pre-Hispanic (AD 900-1521) archaeological remains suggest that potters from the various regions of central Mexico used similar technology for manufacturing ceramics. In general terms, they worked in family workshops and had comparable methods for forming and firing, and created vessels using similar stylistic and formal canons. Although there was a lot of local 
variation in decorative patterns, the majority showed the distinctive trends of that time in Mesoamerica, such as the use of painting to decorate vessels or the addition of three supports to bowls and plates. Here, we will explore why and how potters adopted, modified or rejected three attributes of Spanish ceramics not known in Mesoamerica before: potter's wheel, glazing and majolica ware.

The analysis is based on the integration of previous research on ceramics from central Mexico, as well as on the consulting of several archaeological collections of early colonial ceramics from many contexts in that region, in particular from the Valley of Mexico, where most research on early colonial contexts have been conducted. These collections are deposited in the Departamento de Colecciones Comparativas at INAH in Mexico City. These materials consist of selected samples of diagnostic ceramics found in colonial locations throughout the city. The size and variety of the samples did not respond to any statistical principle and do not provide clues on the total amount and variety of the ceramics excavated in every location. Nevertheless, those collections represent a wide and varied sample of the pottery made and used in the Valley of Mexico during the colonial period. In addition, ethnoarchaeological research was conducted in several pottery towns of central Mexico, in which part of the methods of manufacture and organization of production are still intimately attached to the Mesoamerican world (see Hernández Sánchez 2012).

The focus of study is the early colonial period, following James Lockhart's period division for central Mexico (1992, 427), from $15^{21}$ to $1640-50$, during which - despite the conquest - little changed in the Nahua communities of central Mexico. At that time, the Spanish political institution cabildo was introduced. It concerned the political organization of Spanish settlements and indigenous communities, the monasteries and the labor draft called repartimiento. According to Lockhart $(1992,427)$, these institutions encouraged many Spanish elements to pervade indigenous communities but with limitations, thus little changed in the indigenous framework. In that context native potters encountered the Spanish potter's wheel, the glazing technique and the majolica ware.

\section{Encounters with the Potter's Wheel}

There are different techniques for applying pressure to plastic clay to form vessels. Potters may use only one method, such as casting a vessel in a mold or throwing it on a potter's wheel, or they may combine various methods, for example, making part of the vessels by molding and the rest by applying coils of plastic clay. In some forming techniques, potters perform several operations at 
different stages of the plastic range of the clay (Rye 1981, 21). That is, a section of a vessel may be dried before the rest is made in order to avoid deformation, or the lower walls of vessels made by coiling require the use of softer clay. Often, when the water content of the clay drops below the minimum for the plastic range, handles or other additions are applied. Thus, this part of the process of ceramic manufacture involves not only motor habits mastered by frequent repetition, but also detailed knowledge of the sequence of execution. Both types of expertise are learned by potters and transmitted across generations. As Olivier Gosselain explains based on ethnographic research (2000), these types of expertise are very resistant to change because they are internalized, not visible, and similar vessels can be shaped using other forming methods. The techniques used to form ancient ceramics can be identified from vessels remains alone, as they often leave clear marks on the finished products. However, these marks are often covered by later processes of surface finishing like painting or glazing.

In central Mexico, late pre-Hispanic potters made vessels using a combination of molding and coiling techniques. Molding means to press the clay into or over a mold, and coiling is the use of rolls or "coils" to build up a vessel around a circumference in order to increase the height (Rye 1981, 76, 81). In the Valley of Mexico, for example, molds to form the body and the neck of vessels were horizontal (see Charlton et al. 1992, 106-107; Hernández et al. 1999, 77), that is, they served to create horizontal sections of the vessel. It seems that in that region potters used similar techniques for vessel forming. Differences in this process were related to vessel shape (ollas were made out of more sections than bowls), rather than to vessel use (cooking pots were made in similar way to serving pots) (Figure 13.1). These techniques, in particular the use of molds, promoted standardization in shape and size. The fact that the methods for forming vessels were, in general terms, similar and stable suggests that this kind of knowledge was transmitted without disruption across generations.

We still do not know exactly when the Spanish ceramic technology arrived to Mexico, as this industry is scarcely mentioned in early colonial documentation, and ceramic remains do not offer fine chronological details. It seems that after the conquest, the Spanish colonizers wanted to maintain their European eating habits, and for them this meant eating from the same vessels used at home, such as glazed wares and white tin-enameled majolica wares. Jerónimo de Mendieta $(1980,404)$ mentions in his Historia Eclesiástica Indiana, written between 1571 and 1596, that a master potter from Spain settled in the colony. We can infer that he, or other Spanish potters, started a workshop for Spanishstyle ceramics, such as majolica ware, and introduced the potter's wheel because these vessels were formed with the wheel. 

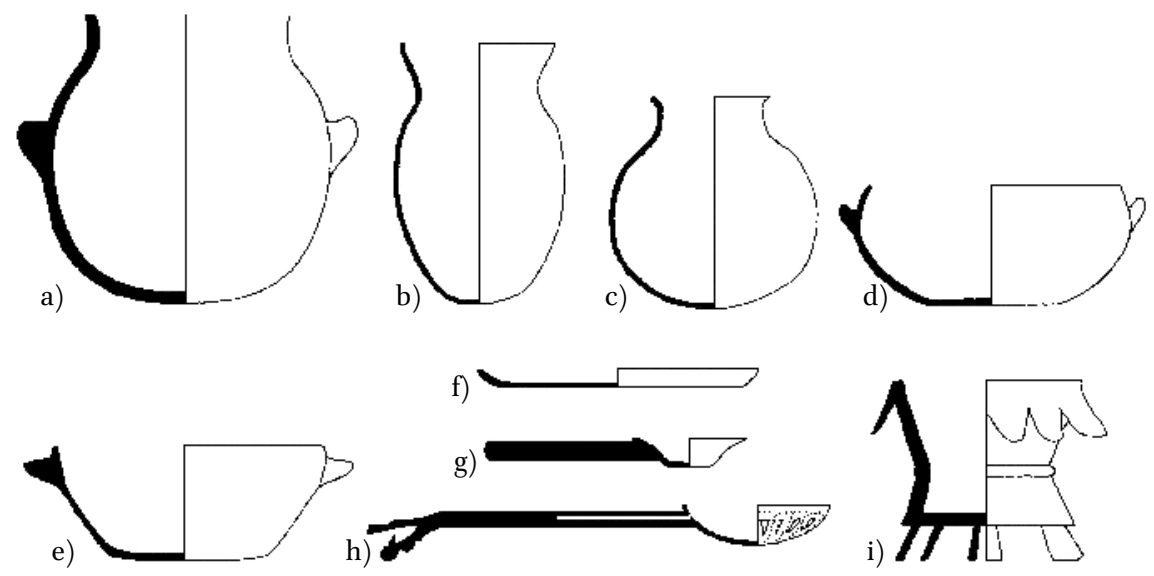

Orange wares

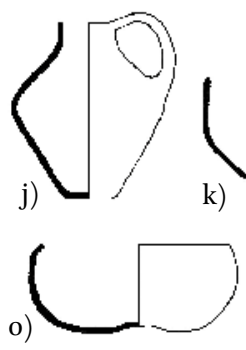

p)
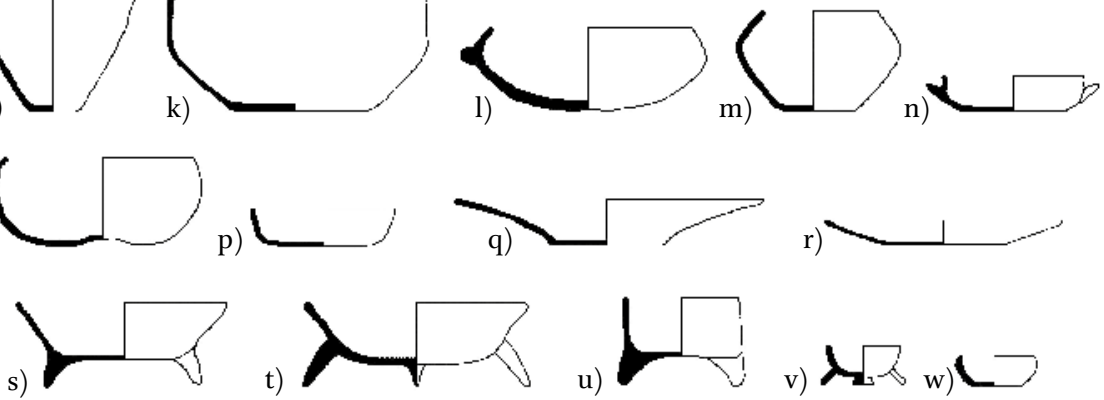

t)
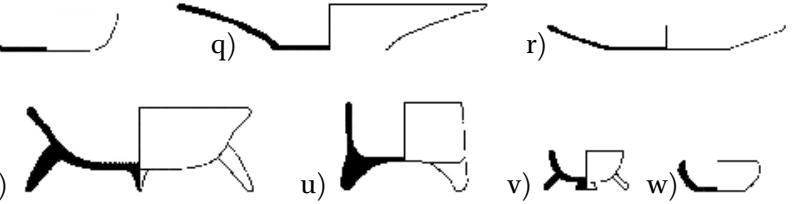

Black-on-orange wares
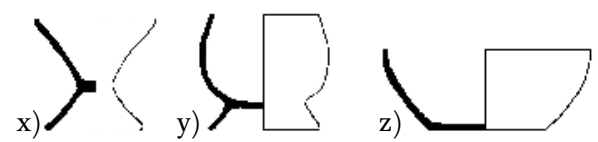

u)
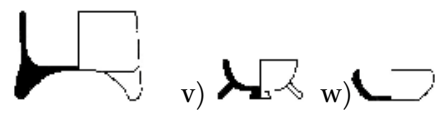

$\mathrm{x})$

z)
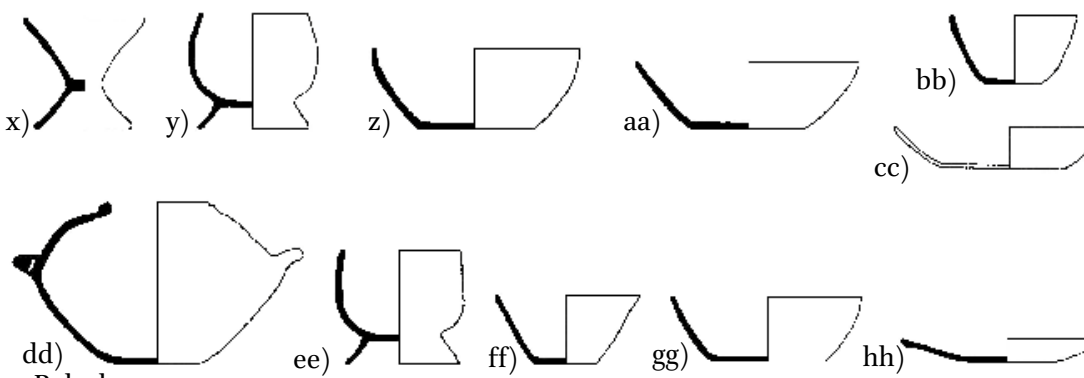

ee)
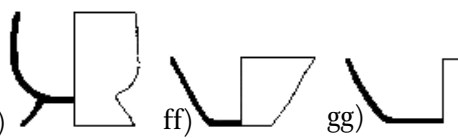

hh)

cc)

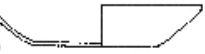

FIGURE 13.1 Late pre-Hispanic vessel shapes in the Valley of Mexico: (a-c) ollas; (d) basin with upright walls; (e) basin with flaring walls; (f) comal; (g-i) censers; (j) pitcher; (k) basin with upright walls; (l-m) hemispherical bowls; (n) bowl with upright walls; (o) hemispherical bowl; (p) bowl with upright walls;

(q) bowl with flaring walls; ( $\mathrm{r}$ ) dish; (s) tripod bowl with flaring walls;

$(\mathrm{t})$ molcajete; $(\mathrm{u})$ bowl with upright walls; $(\mathrm{v}-\mathrm{w})$ miniatures; $(\mathrm{x}-\mathrm{y})$ goblets; (z-cc) bowls with upright bowls; (dd) bowl with composite silhouette; (ee) goblet; (ff-gg) bowls with upright walls; (hh) plate. Not scaled 
The first Spanish-style workshops for majolica ware were established in Mexico around the 1530s, considering the morphology and style of the earliest majolicas produced in Mesoamerica (Lister and Lister 1978, 22). Likely at the same time the potter's wheel was introduced to form vessels, as this implement was characteristic of those kinds of workshops. Forming vessels with the centrifugal force of the wheel was the common method for pottery manufacturing at that moment in Spain (Sánchez Cortegana 1994), and it had a long tradition in the old world. It was present in southern Levant as early as the beginning of the 4th millennium BC (Roux 2003, 2). Mexican majolica vessels, as well as other vessels made with the wheel, show the typical attributes associated with throwing: spiral rhythmic grooves and ridges on the interior of the base, compression ridges on the interior of the walls, or straight, parallel grit dragmarks on the base (Rye 1981, 75).

After the conquest, indigenous potters in central Mexico continued using the same methods for forming vessels. Remains of indigenous-style ceramics, from contexts identified as early colonial, show that vessels were made with horizontal molds (Figure 13.2). In the case of ollas, juncture marks show that they were made using two or three horizontal molds as in pre-Hispanic times. Also, as in early times, bowls were made with one horizontal mold. Even ceramics of indigenous style but with new morphological or decorative traits characteristic of the early colonial period were made with horizontal molds. For example, in colonial times there were many innovations in the manufacture of indigenous red wares; many new shapes and decorations appeared. Nevertheless, manufacturing marks visible on the vessels show that they continued to be made with molds. This means potters in indigenous-style workshops did not adopt the potter's wheel. We can propose several reasons for this. First, the new method of manufacturing did not represent a technical improvement, as some modern researchers believe (e.g., Foster 1960, 101; Katz 1977, 124-125). Some kinds of vessels, such as small bowls and pitchers, could be made faster with the wheel, however, bigger forms such as large cazuelas or ollas were difficult to make by that method, as potters consulted during ethnographic research in central Mexico clarified (Hernández Sánchez 2012, 170-172). Second, the connection between particular clay recipes, vessel shapes and method of manufacture was the result of a vast pottery experience accumulated through generations. Potters could not simply replace the ancient forming method in favor of the wheel without also incorporating important changes in the clay "recipes" and morphology of the vessels, as present-day potters further explained (Hernández Sánchez 2012, 170-172). Third, this was one of the most difficult parts of the process of manufacturing of vessels. It involved motor habits mastered and internalized by frequent repetition and required knowledge. Today potters acquire the knowledge and bodily skills required for forming 
Vessel shapes made by molding and coiling
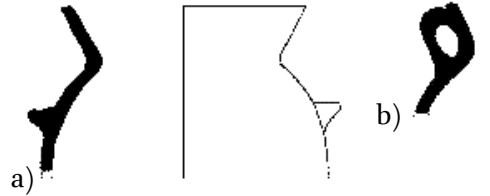

Lead-glazed wares
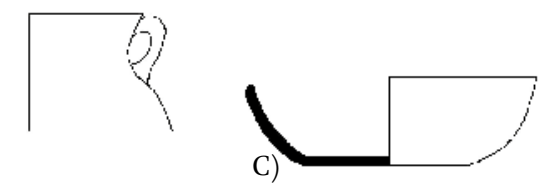

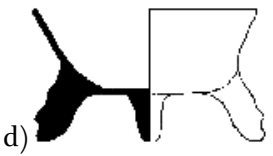

Lead-glazed wares e)

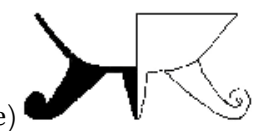

Black-on-Orange wares
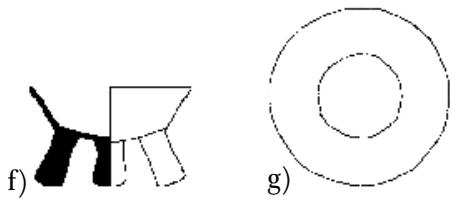

g)

$>2$
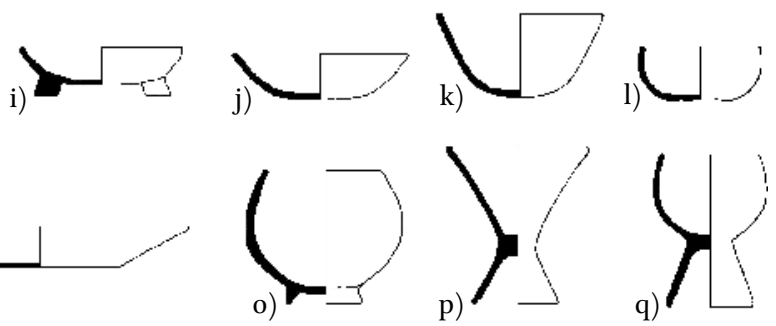

Vessel shapes made with the whell

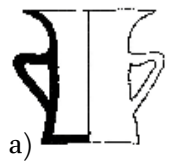

b)
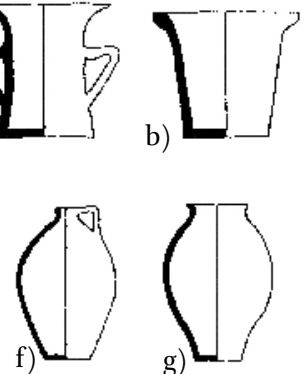
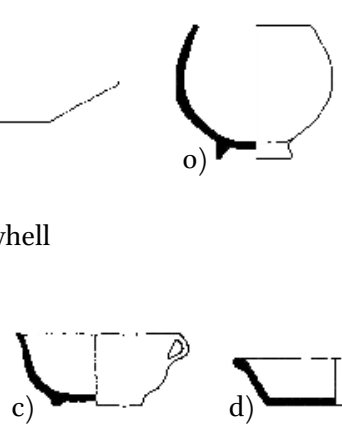
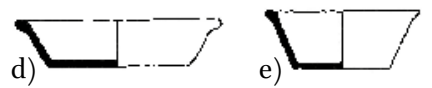
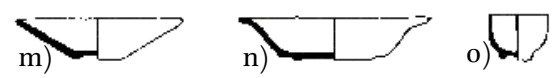

p)

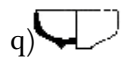

FIGURE 13.2 Shapes of early colonial serving vessels from the Valley of Mexico: vessel shapes made with molding and coiling: (a-b) ollas (based on Charlton et al. 2007, Figure 68); (c) hemispherical bowl (based on Charlton et al. 2007, Figure 69); (d) tripod molcajete (based on Charlton et al. 2007, Figure 66); (e-f) tripod bowls (based on Charlton et al. 2007, Figure 15); (g) plate; (h-i) tripod bowls (based on Charlton et al. 2007, Figure 23; Rodríguez Alegría 2002, Figure A.1); (j-m) bowls; (n) plate; (o-q) goblets (based on Charlton et al. 2007, Figure 26; Rodríguez Alegría 2002, Figure A.1). Vessel shapes made with the potter's wheel: (a-b) bacín; (c) bacinilla; (d-e) lebrillo; (f) cántaro; (g) tinaja; (h) orza; (i) jarra; (j) pitchel; (k) hidroceramo (botija); (l) albarelo; (m-n) plato; (o) taza; (p) pocillo; (q) escudilla (based on Deagan 1987, Figure 4.1) 
vessels within the family. Potters learn from parents or uncles, often as children, as the workshop is usually the core of family life (Hernández Sánchez 2012,172 ). The method of forming is therefore intimately related to their understanding of ceramic-making and to family knowledge transmitted for generations, and because of this, potters do not easily change it. In early colonial times, it probably was the same. For all these reasons, the method of forming was very conservative.

In the early colonial Valley of Mexico, some glazed vessels were made with the wheel while others were made by mold. This can be recognized in the vessels themselves; in particular in common and simple pots for cooking and serving, as their surface still has some visible marks of the process of forming (see Hernández Sánchez 2012, 112). Vessels made with a potter's wheel were majolica ware or were lead-glazed ware and had specific shapes. These were mainly plates with ring base, cups, pitchers, lebrillos (basins), bacines (basins with high walls), botijas (amphorae for olive oil), albarelos (high drug vases) and candleholders (see Figure 13.2). All of them had Spanish antecedent and names taken from the Spanish vessel repertoire (Lister and Lister 1987; Sánchez 1998). A few of them were clearly related to Spanish uses, such as the olive jars, which were lead-glazed in the interior to avoid filtration (Goggin 1960). The rest could be associated to Spanish uses, such as the albarelos, which were medicine containers, or the lebrillos, which were chamber pots, but these uses were not exclusive Spanish customs. In contrast, vessels with shapes of indigenous origin, such as ollas, cazuelas and bowls, were made with molds. This may suggest that these two groups of vessels were made in different workshops. It seems that after the conquest indigenous-style workshops continued using the same methods of manufacture for producing the known repertory of vessels. At the same time, Spanish-style workshops for manufacturing Spanish-style vessels used the wheel.

Majolica wares were all made by wheel. Thus, as a rule, vessels with typical Spanish-style shapes were made by wheel. A possible exception is a serving ware present during the sixteenth century in Mexico City but made, according to chemical analysis of the clay, in Michoacán, west of central Mexico (Fournier et al. 2007). These vessels were decorated with white slip covered with lead glaze, which has the appearance of majolica, although its glaze is not blended with tin. Archaeologists call them Indígena Ware (Lister and Lister 1978, 19). Observation suggests that these vessels were made with a mold as the typical marks of a wheel were not detectable. However, as slip and glaze have covered large parts of the vessel's surface, it is still necessary to conduct microscopic analysis to confirm this hypothesis. The vessels show Spanish-style shapes, such as plates and small bowls with Spanish-style proportions, but are decorated with motifs both of Spanish and indigenous origin. 


\section{Encounters with the Glazing Technique}

Once a vessel is formed, but also during the process of forming, a potter generally finishes its surface by rubbing a tool against the leather hard clay or by applying a slip (fluid suspension of clay in water of different color than the vessel clay) to modify its texture and light reflecting qualities (Rye 1981, 89). Surface finishing requires particular motor habits, but also experience with clay properties. Both kinds of knowledge are learned and transmitted across generations. However, as this part of the process of ceramic-making is visible on the vessels, it may be influenced by other potters and by users. The methods used to finish ancient ceramics can be identified by observing vessel remains, although normally earlier stages of this process are covered by later stages, leaving only the later visible. Potters may give variable attention to the finishing of the surface of a vessel. They may only smooth the surface, that is, rub the vessel until it acquires a regular texture but a matte appearance. They may burnish the surface, that is, rub the surface regularly but the tool is used directionally so that a pattern may be produced, and the appearance is a combination of matte and luster. On the other hand, they may polish the vessel, producing a regular surface with uniform luster (Rye 1981, 89-90).

Late pre-Hispanic potters of the Valley of Mexico gave a similar surface finishing that was simple and without extra decoration to common vessels, such as those for cooking, storage and transportation. The surface of this kind of objects shows the natural color of the fired clay, which is generally orangebrown (Blanton and Parsons 1971, 304). The surface is relatively well smoothed but hastily burnished, that is, strikes left by the burnishing tool can be seen (Blanton and Parsons 1971, 304). Potters also made serving vessels with painted decoration. These objects show more variety in surface finishing. The most frequent were orange bowls and plates with black painted decoration; archaeologists today, name them today Black-on-Orange vessels (Whalen and Parsons 1982, 441) (Figure 13.3). These objects maintained the natural orange-brown color of the fired clay. Potters also made serving vessels with red decoration; archaeologists today name them Red Ware (Cervantes et al. 2007, 279; Tolstoy 1958; Whalen and Parsons 1982, 446) (Figure 13.3). They were, as a rule, better finished than vessels with black decoration. Their orange-brown surface was well smoothed and relatively well burnished. Some of these vessels were additionally decorated with black or white paint or with incisions. Potters also made other serving vessels with more complex decoration and higher quality. These objects were painted with red, orange and black designs in the same style as the famous late pre-Hispanic polychrome "codex style" ceramics and were finely polished to reach a glossy finish (Whalen and Parsons 1982, $441,446)$. 
a)
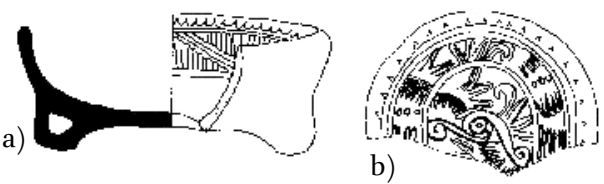

c)

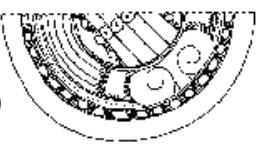

e)

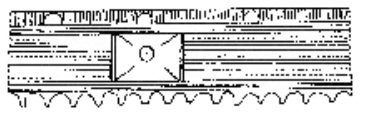

d)
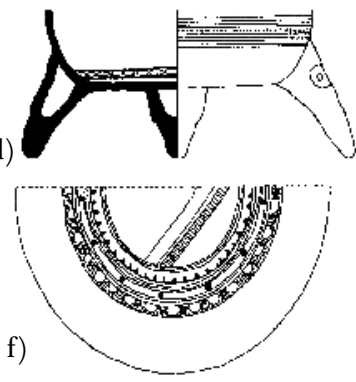

g)

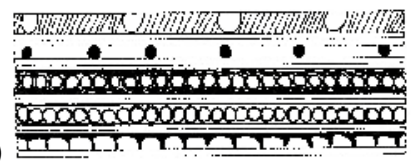

h)
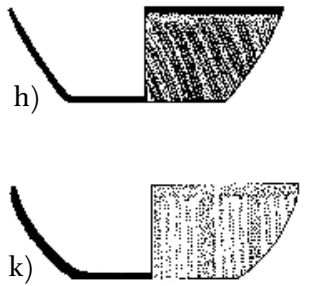

i)
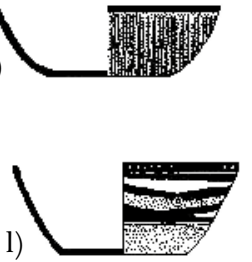

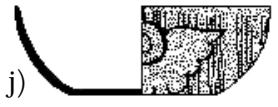

$\mathrm{m})$

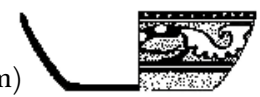

FIGURE 13.3 Patterns of decoration on late pre-Hispanic ceramics from the Valley of Mexico: (a) early Aztec Black-on-Orange tripod bowl (based on Minc et al. 1994, Figure 6.2a); (b) early Aztec plate (based on Cervantes et al. 2007, Figure 14); (c) early Aztec plate (based on Cervantes et al. 2007, Figure 23); (d) late Aztec tripod bowl (based on Cervantes and Fournier 1995, Figure 2); (e) decoration pattern on late Aztec plate (based on Cervantes and Fournier 1995, Figure 8); (f) late Aztec plate (based on Cervantes and Fournier 1995, Figure 5); (g) decoration pattern on late Aztec bowl (based on Cervantes and Fournier 1995, Figure 9); (h-j) late Aztec Black-on-Red bowls (based on Cervantes et al. 2007, Figure 61); (k) late Aztec White-on-Red bowl (based on Cervantes et al. 2007, Figure 39); and (l-m) late Aztec White-and-Black-on-Red bowls (based on Cervantes et al. 2007, Figure 43). The early Aztec period corresponds to ca. AD 900-1350 (Brumfiel 2005, Sanders et al. 1979); the late Aztec period to ca. AD 1350-1521 (Cervantes et al. 2007, 280; Charlton 2000; Hare and Smith 1996)

On the eve of the conquest, potters in central Mexico finished their vessels in similar manner. They shared not only the methods of rubbing the surface, but also the high attention given to the surface of some serving objects. That is, in every region of central Mexico there were repertories of fined polished vessels with polychrome painted decoration (see Hernández Sánchez 2012, 60-62). Surfaces were not decorated with vitreous glaze in pre-Hispanic Mesoamerica. Plumbate ware, a widespread trade pottery made in the Soconusco region on the coast of Guatemala during the tenth and eleventh centuries, has some 
similarity to glazed ceramics. These ceramics have a ferruginous slip, which after firing has an iridescent gray-orange color (Shepard 1948). Although this slip is vitrified in some places due to the particular mineralogical composition and firing, it is not a high-fired vitreous glaze (Rice 1987, 20). This technology, however, did not continue in Mesoamerica after the eleventh century.

We still do not exactly know when the Spanish ceramic technology arrived to Mexico, but it seems that there was some very early Spanish interest to produce glazed vessels. In a document sent by Alonso Figueroa, Chantre of Oaxaca, to Charles V in 1529 he states: "Con trabajo e ingenio alcancé el vidriado que no tenían, un plato en que comer sino venía de Castilla"1 (cited in López Cervantes 1976, 15). However, as he says, wares were still imported from Spain. A few later sources, the Florentine Codex (Sahagún 1961, X, 839), apparently prepared as early as 1547 and completed in 1569 (D'Olwer and Cline 1973, 193), the Historia Eclesiástica Indiana (Mendieta 1980 [1571-1596], 404) and a letter of Viceroy Lorenzo Suárez de Peralta sent dated in 1583 (Cervantes 1939, I, 18); show that by 1570 - 158 os the production of glazed wares was already established in the colony. In that letter sent to the alcalde mayor of Michoacan, Suárez de Peralta mentions:

... por cuanto por parte de los naturales de la ciudad de Patzcuaro, que son oficiales de hacer platos y escudillas de loza vidriada y otras piezas de barro, me ha sido dada relación que la justicia de dicha ciudad, proveyó veedores de este oficio para que viesen y visitasen la obra que se hazía, para que siendo tal se pudiese vender y no lo siendo se los quitase y no se vendiese. Y agora estos indios olleros que no son ni han sido ni pueden ser oficiales de dicho oficio ni lo saber hacer dichos platos mal hechos y de donde se sigue fraude y engaño ... y me pidieron les mandase dar y diese mandamiento para los que son tales oficiales usen el dicho oficio y no los olleros .... ${ }^{2}$

Archivo General de la Nación, Ramo Indios, Vol. II expedient 718; LÓPEz CERVANTES 1976, 15

1 "With work and talent I was able to make glaze, as they did not have a plate to eat if it did not come from Castile" (my translation).

2 "...concerning the inhabitants of the city of Patzcuaro, which are officials in the trade of making glaze ceramic plates and bowls and other objects of clay, it was informed to me that the justice of the mentioned city, provided observers of this trade in order to observe and visit the works made, and in the case they were right they could be sold and if not they could be taken and not sold. And now these indigenous pot makers which are not and were not and cannot be officials in this profession and cannot make those wrong made plates and where fraud and tricks are followed ... and they asked me to give an order for those who are officials could practice this profession and not the pot makers..." (my translation). 
This shows that, by that time, not only the manufacture of glazed ware was well established, but also that indigenous potters were using this technique. The glaze technique consisted of the application of a mixture of lead oxide, silicate and clay to the surface of a fired vessel (Charlton et al. 2007, 485-486). After that, the vessel was fired again at a higher temperature, and the glaze material melted and fused to the surface, obtaining a physical structure similar to glass (Rye 1981, 44). The result was a glossy vessel with brownish or greenish glaze.

After the conquest, the surface finishing and decoration of indigenous-style vessels manifested notorious changes. We can recognize two major trends. On one side, serving vessels evidence great impulse of creativity and innovation. Potters modified parts of the surface finishing and decoration that existed before the conquest, and experimented with new techniques. In particular, this was the case for the red wares in which new styles and motifs of decoration are observed (see Charlton et al. 1995, 143; Fairbanks 1966). At the same time, the manufacture of other decorated serving wares decreased and was a bit simplified, such as the orange vessels with black decoration (see Charlton et al. 2005, 2007, 440; Garraty 2006, 368) and the polychrome vessels (Lind 1994, 81). On the other side, a second trend was that the surface finishing of cooking vessels was simplified while a new technique, the lead glaze, became quite popular.

The application of lead glaze for decorating vessels was an early Spanish introduction. It seems that this technique was readily accepted by native potters and was established in indigenous workshops by the second part of the sixteenth century. Sahagún $(1961,839)$, in his description of indigenous potters and the pottery craft, mentioned that they made a variety of pre-Hispanic wares but also glazed vessels. This reference could date the establishment of this technique among indigenous potters between 1547 and 1569, when the production of the Florentine Codex is estimated (D'Olwer and Cline 1973, 193), although it could occur earlier. Unfortunately, the morphology and archaeological context of indigenous-style glazed vessels do not provide more chronological detail. For example, in several places in the Valley of Mexico typical pre-Hispanic vessels with lead glaze, specifically molcajetes (bowls with striated interior bottom for grinding chili sauces), have been found. These objects are dated for the early colonial period (AD 1521-1620), according to their morphology and context (Charlton et al. 2007, 486); however, we are not yet able to date them with more precision. Molcajetes were clearly for indigenous users. Their function as grinders for chili sauces was pre-Hispanic as well as their shape and decoration. In addition, other kinds of indigenous-style vessels were also glazed, like ollas and cazuelas. 
Lead glaze as surface finishing required different types of effort and energy than the typical pre-Hispanic surface treatments. These vessels did not require finishing the surface with detailed burnishing, as the glaze covered most of the previous process of finishing. However, these vessels required two firings and higher temperatures, and therefore a larger amount of fuel. Even with the higher efforts this involved, indigenous-style workshops implemented this technique, as is evidenced by the presence of glazed vessels with indigenousstyle forming methods and morphology. Although glaze notably altered the appearance of these vessels, it was relatively easy to implement without modifying other parts of the process of manufacture (with exception of firing). The fact that this technique was not only implemented in serving wares that are normally those in which potters' influences are reflected, but also in cooking wares, shows that lead glaze had an important impact on the indigenous pottery. This was not exceptional, however; Mesoamerican potters had always been open to new forms of surface finishing and decoration as the variety of pre-Hispanic vessel repertoires in different regions and epochs show.

\section{Encounters with Majolica Wares}

The shape of ceramic objects is the result of several interconnected variables: function, physical properties of materials, forming method and aesthetic preferences of the potters. Therefore, the form of the vessel may change even if its function remains the same. Likewise, shifts in function may not be evident in its shape. The techniques to make particular vessel shapes can be learned and transmitted through generations. Nevertheless, potters can easily modify their size, proportions and silhouette by the influence of users, relatives, neighbors or fellow potters. In addition, potters normally produce particular assemblages of vessels. That is, they make a specific variety of vessels for cooking, as well as a variety of vessels for serving food and drink, and also several objects for ritual purposes, such as censers. Although late pre-Hispanic central Mexican potters made a wide variety of vessel forms, the shape repertoire was, in broad terms, similar. The most common vessels designed for cooking, storage and transportation were high-necked and short-necked ollas of various sizes, as well as basins with upright walls or flaring walls (see Blanton and Parsons 1971, 299; Cervantes et al. 2007, 283-284; Whalen and Parsons 1982, 438-441, 450). There were also simple hemispherical bowls, comales and molcajetes. Common vessels for serving were bowls, with or without supports, and plates.

In late pre-Hispanic central Mexico, vessels for serving were often decorated. Overall, decorative techniques for ceramics take into account the possibilities 
offered by the various properties of the clay during the process of drying and the effects of firing. Knowledge related to these aspects can be learned and transmitted across generations. However, as this part of the process of ceramicmaking is highly visible, potters may easily make changes influenced by users, relatives, neighbors or colleagues (see Gosselain 2000, 191). Designs and patterns executed in a particular decoration technique may even be more easily modified as this does not require extra technical knowledge but only new ideas resulting from inspiration, imitation or reinterpretation.

On the eve of the Spanish conquest, most of the decoration on ceramics in central Mexico was made with painting (see Cervantes et al. 2007; Noguera 1954; Whalen and Parsons 1982). In addition, there was often a relationship between vessel form and decoration. Common vessels designed for serving food and drink, such as the Black-on-Orange ware, were painted with patterns of black lines and curvilinear motifs (Cervantes et al. 2007, 280; Charlton 2000; Hare and Smith 1996), and were bowls with tripod supports and plates (Blanton and Parsons 1971, 294; Whalen and Parsons 1982, 441, 450) (see Figure 13.3). In contrast, the red wares were ornamented with large sections of thick and well-polished red paint, and often black designs; less frequently they also included white painting and incisions (see Blanton and Parsons 1971, 309; Cervantes and Fournier 1995, 100; Cervantes et al. 2007, 300; Whalen and Parsons 1982, 446, 450) (see Figure 13.3). These red vessels were mostly bowls and had no appendages at all. Both black-on-orange and red wares were common serving vessels. In general, the painted designs were simple, schematic and hastily done, which suggests that they did not play a special role in the communication of meaning relevant to the contexts where these objects were to be used. In contrast, potters also manufactured some objects of superior quality with complex pictographic decoration (Vega 1975, 25). The painted motifs were part of the symbolic corpus of central Mexican pictographic writing, and were associated with important meanings in the context of Mesoamerican ceremonialism, such as piety, preciousness or nobility (see Hernández Sánchez 2005). In contrast to black-on-orange and red wares, these fine polychrome vessels had a large formal inventory (see Hernández Sánchez 2005, Table 8.2).

The first Spanish colonizers wanted to maintain their eating habits, and for them this implied eating from the same vessels used at home, such as glazed wares and white tin-enameled majolica wares. In the beginning, Spanish ships brought loads of ceramics to the Americas. For example, in the Dominican Republic typical fifteenth-century Andalusian service wares, which still evidence Arabic stylistic traits, have been found (Deagan and Cruxent 2002, 139). After the conquest, Spanish ceramics also arrive to Mesoamerica (see Fournier 1996, 452; Lister and Lister 1978; Sánchez 1996), but probably not in large quantities and not common vessels as transoceanic transportation was costly and 
reserved for other basic items such as weapons, wine and oil (Sánchez 1996, 128). In addition, after the establishment of the Manila Galleon Trade in 1573, a few Chinese porcelains arrived in Mexico City (Charlton et al. 2005, 62; Lister and Lister 1978, 10).

Majolica wares were very popular at that time in Spain (see Pleguezuelo 1999; Sánchez 1994). These vessels, after a first fire, were covered with a mixture of tin, lead and silicate, and decorative motifs painted with metallic oxides; following a second firing, the vessel acquired a white milky glaze and decorative patterns in various colors (Lister and Lister 1982, vii). The first Spanish-style workshops for majolica ware were established in Mexico City. According to the Listers $(1978,22)$, this occurred around 1530s, considering the morphology and style of the vessels made. Afterwards the production was moved in the $1580 \mathrm{~s}$ to the city of Puebla, where in the seventeenth century innovations occurred with majolica wares and new shapes and colorful decorations appeared (see Lister and Lister 1984, 87). The production became so significant that Mexican majolica wares were exported to other Spanish colonies in the Americas (e.g., Duarte and Fernández 1980; Goggin 1968, 223). However, both the indigenous and the Spanish traditions of ceramics were apparently produced in different workshops. The excavation of a colonial workshop from the end of the sixteenth century and beginning of the seventeenth century in Mexico City, for example, revealed that only majolica wares were produced there (Gámez 2003, 236). Furthermore, the guild regulations of the seventeenth century for majolica potters of Puebla suggest that they produced only common and fine-grade glazed wares. That is, the fifth statute states:

Que haya de tener separación los tres géneros de loza fina, común y amarilla, que se entiende ollas y cazuelas, y otros vasos, jarros colorados, no pueden hacer loza fina, ni común, menos que habiéndose examinado para ello de forma que cada uno ha de labrar, sólo el género de que se examinarse, y no otro ninguno, si no es que se comprende todo en su examen. ${ }^{3}$

NOVELO 2007, 101

The statute suggests that there were workshops specialized in Spanish-style ceramics. They produced majolica ware, but also used the potter's wheel and

3 "It should be made a separation between the three grades of ware, fine, common and yellow, which is understood as the jars, cazuelas and other vases, red pitchers, they cannot made fine or common wares, at least they are examined for this in that way everyone can only produce the grade of ware for which he has been examined, and not other grade at least is included in his exam" (my translation). 
manufactured vessel shapes that were not made before in Mesoamerica, such as particular forms of cups and plates. They used new decorations, as well. Following the Spanish tradition (see Lister and Lister 1987), majolica ware made in Mexico was decorated with bands of curvilinear and geometric motifs painted in several colors, mainly blue, yellow and orange. Compositions were similar to those of the majolica vessels produced at that time in workshops around Seville (see Charlton et al. 2007; Lister and Lister 1978, 1982, 1987). Potters that specialized in indigenous-style red ware vessels incorporated a few decorative elements of these new ceramics (Figure 13.4). However, indigenous and Spanish decorative traditions were maintained separately until the end of the early colonial period. Red wares continued to be made in the late colonial period, but their decoration was increasingly different than that of earlier times. Some specialists consider Indígena Ware (vessels with white matte slip covered by lead glaze) as indigenous imitations of majolica ware (Charlton et al. 2007,

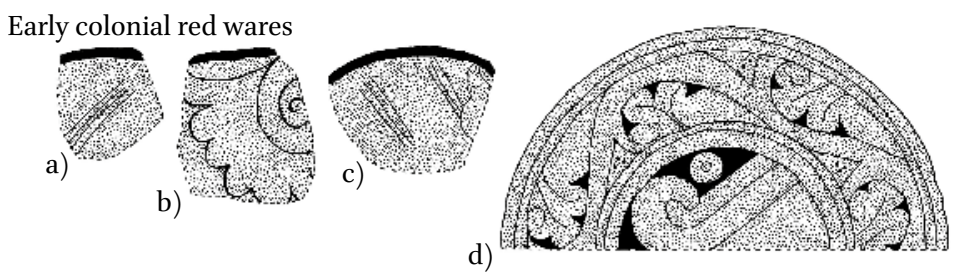

Early colonial majolica wares
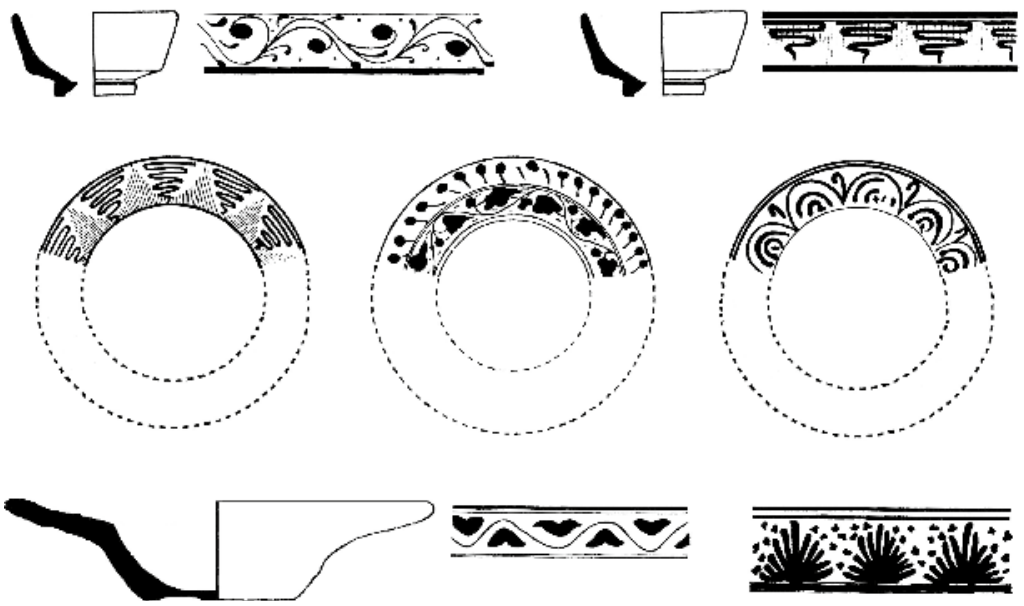

FIGURE 13.4 Patterns of decoration on early colonial wares from the Valley of Mexico. Red wares: (a-b) bowls with flared walls (based on Charlton et al. 1995, Figure 6); (c) bowl with upright walls (based on Charlton et al. 1995, Figure 5); (d) plate with interior decoration (based on Charlton et al. 1995, Figure 8). Majolica ware all based on Lister and Lister 1987, Figure 85 
470-471; Lister and Lister 1978, 21). However, we do not yet have enough data to confirm that those vessels were made in indigenous-style workshops.

It seems that during the first generations after the conquest there were not many points of conflict between indigenous and Spanish potters or between indigenous potters and colonial authorities. This is suggested by the scarcity of administrative documents and other written sources related to this topic. The creation of pottery guilds and regulations in the seventeenth century shows, however, that by the late colonial period Spanish-style workshops were competing with other pottery workshops. Craft guilds, like the guild of majolica potters in Puebla, were established in particular sectors of the city. They examined their members and established a hierarchy according to their knowledge and experience, and created many rules for their work and products (Carrera Estampa 1954). This form of organization gave way to workshops not based on family relations but rather on occupation relations. This was a clear contrast to indigenous-style workshops based on the family. Likely, this resulted in the two kinds of workshops developing different forms of personal relations and knowledge transmission.

\section{4 \\ Indigenous Pottery Technology in Central Mexico after the Conquest}

It seems that Spanish-style workshops in early colonial central Mexico were maintained separately from indigenous-style workshops. This is recognized in the use of different methods of manufacture, different shapes and different decorations in vessels from both traditions. Despite that separation, indigenous potters were well aware of the newcomer ceramic technology, and selectively incorporated and readapted various elements. The potter's wheel was not really implemented in indigenous-style workshops. This method did not represent an improvement to the known technology. Therefore, there was no reason to modify the most stable part of the production sequence, which was deeply rooted in potter families for generations and was closely associated with their own conceptualizations about pottery (see Hernández Sánchez 2008). The glazing technique was indeed a novelty that attracted the attention of indigenous potters and was widely implemented early in the colonial period. This decoration was showy and relatively easy to create. The challenging part was that vessels needed to be fired twice, and the second fire required a temperature hot enough to reach the melting point of the glaze. The concomitant need to collect and to manage greater amounts of fuelwood might have had important impacts on local environments and allocations of time and labor. 
It seems, however, all this was not a limitation as lead-glazed indigenous-style vessels were broadly distributed in early colonial times. This new style of decoration simplified the process of surface finishing, as it was not necessary to burnish the vessel in detail; it also made the surface impermeable. Still, the glossy finish was probably the most attractive quality for potters. Some early vessels were glazed in areas where water-resistance and reduced labor from burnishing were not important criteria. For example, tripod molcajetes had glazed supports.

Decoration with lead glaze was, without a doubt, the aspect of the Spanish ceramic technology most implemented by indigenous potters. Nevertheless, early colonial indigenous-style vessels also show other decorative elements taken from the Spanish tradition. The majority, however, were not copies of decorations of Spanish-style ceramics but reinterpretations of Spanish motifs. For example, a few colonial red wares were painted with black curvilinear motifs which had some resemblance to motifs painted on the earliest majolica wares in Mexico City (see Charlton et al. 2007, 449, 472-477). However, this kind of adornment was rather exceptional. Most of the new decorations with Spanish influence were not taken from Spanish-style vessels, but from other media. For example, a number of early colonial native black-on-orange vessels were painted with images of flowers, fishes, birds, leaves and ears of wheat (Figure 13.5). Most of these images were not new in Mesoamerican ceramics, but they were not painted before in this ware. Their style of representation was also a bit different from earlier figural depictions, and showed a little Spanish influence. In addition to decorative elements, indigenous potters also incorporated a few vessel shapes of the Spanish tradition. For example, extended plates or small cups with flat handles were the most common forms of majolica wares (Charlton et al. 2007, 463) while they, in that particular shape, were not made before in Mesoamerica. These vessel forms were incorporated into the wide, formal, early colonial repertoire of red wares. The rest of the morphological novelties were details for embellishing the vessels rather than for modifying their function. For example, red wares incorporated ring bases and cover lids that were characteristic of Spanish vessels at that time. In addition, as in the case of decoration, some morphological innovations were not imitation of European ceramics but were inspired by the new culture that arrived to Mesoamerica. This was clearly the case of vessels with supports modeled in new shapes inspired by colonial animals, like pig hoofs and lion claws.

Thus, central Mexican potters, after the encounters with the potter's wheel, the glazing and the majolica ware, openly and selectively incorporated or reinterpreted a number of elements of Spanish technology, in particular in vessel decoration and morphology. They were also inspired by the new colonial world 


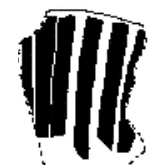

a)

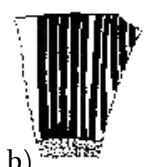

b)

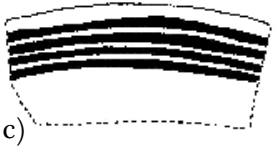

c)

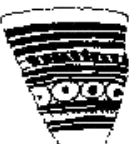

d)

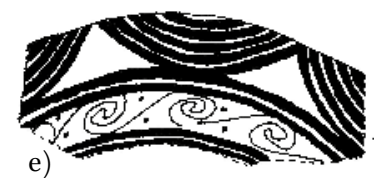

e)

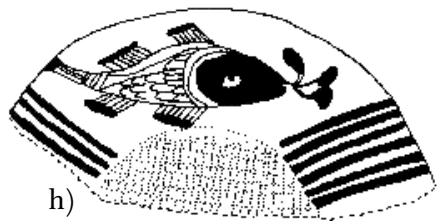

h)

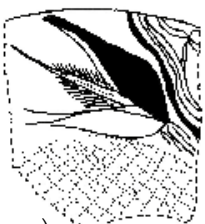

g)
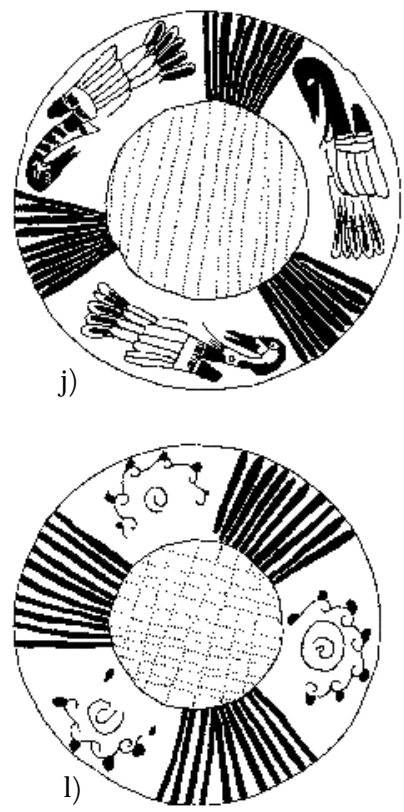

FIGURE 13.5 Patterns of decoration on early colonial Black-on-Orange wares from the Valley of Mexico: (a-d) molcajetes and tripod bowls (based on Charlton et al. 2007, Figure 12); (e-g, k) molcajetes and tripod bowls (based on Charlton et al. 2007, Figure 13); and (h-j, l) molcajetes (based on Charlton et al. 2007, Figure 14)

and created new decorative compositions, which were more figural and iconic than in pre-Hispanic times. In contrast, the Spanish ceramic technology adopted practically nothing from the indigenous tradition, neither in Seville nor in Mexico City. Peoples associated with the colonial rule in the Valley of Mexico used indigenous-style pottery. For example, many red wares have been found in the most prominent area of Mexico City (Rodríguez Alegría 2003), and in 
churches and convents elsewhere in central Mexico. However, Spanish-style workshops did not produce vessels of the indigenous-tradition. This is suggested by the lack of indigenous-style vessels made with the wheel. The reason for this rejection might be in part related to the colonial situation; namely, the need of the colonizers to maintain the cultural association with their fatherland or the conviction of European technological superiority. However, part of the reason was probably of technical nature. As was the case for indigenousstyle workshops, Spanish-style workshops were attached to their own methods of manufacture.

In brief, early colonial central Mexican potters had various reactions to the encounter with Spanish ceramics. On one hand, they selectively incorporated and reinterpreted elements of decoration and morphology, and were inspired by the world brought by the Spaniards in the creation of new decorative motifs. On the other, they did not implement technical devices that they did not need, such as the potter's wheel. In my opinion, the inclusion of Spanish decorative elements in the vessels was not related to attitudes of submission, just as the rejection of Spanish devices was not related to attitudes of subversion. A potter's work followed the same dynamics as in ancient times, that is, they conserved their familiar methods of forming while they adapted the visible aspects of the vessels to the situation of the present time. These two basic characteristics, existing at the same time, are evident in the entire ceramic production of the pre-Hispanic history. Thus, in the early colonial period the incorporation, adaptation or rejection of Spanish elements was not politicized by potters. They just wanted to maintain their way of living and adapt to the new post-conquest society.

After the early colonial period, ceramic-making in central Mexico experienced more changes. Clay recipes, method of forming and firing technology were consistent with ancient times. Whereas morphology, finishing and decoration were so modified that vessels became gradually more differentiated from their pre-Hispanic antecedents. This trend continues to the present day (Hernández Sánchez 2012, 207). Thus, today vessels do not look like those of the precolonial past. In central Mexico, the majority of the production is now concentrated on lead-glazed wares, which are embellished with motifs not related to ancient decorations. The shapes continue to resemble ancient forms although potters have made many innovations in minor formal details. Nevertheless, the method of forming has been maintained. Vessels continue to be made with molds and coiling, not with the potter's wheel. This is intimately related to the core of this tradition, and therefore it is sign of the continuation of the pre-Hispanic ceramic culture until the present time. 


\section{Acknowledgments}

This study presents results of the research project "Ceramics and Social Change. The Impact of the Spanish Conquest on Middle America's Material Culture" carried out from 2006 to 2010, under the generous support of a VENI grant from the Innovational Research Incentives Scheme of the Netherlands Foundation for Scientific Research (NWO) and the Faculty of Archaeology of Leiden University.

\section{References}

Blanton, Richard E., and Jeffrey R. Parsons. 1971. "Apendix I: ceramic markers used for period designations." In Prehistoric settlement patterns in the Texcoco region, Mexico, Memoirs of the Museum of Anthropology No. 3, edited by Jeffrey R. Parsons, 255313. Ann Arbor: Museum of Anthropology.

Brumfiel, Elizabeth M. 2005. "Ceramic chronology at Xaltocan." In Production and power at Postclassic Xaltocan, edited by Elizabeth M. Brumfiel, 117-152. Pittsburgh: University of Pittsburgh.

Carrera de la Stampa, Manuel. 1954. Los gremios mexicanos. La organización gremial en Nueva España, 1521-1861. Mexico: Edición Iberoamericana de Publicaciones.

Cervantes, Enrique A. 1939. Loza blanca y Azulejo de Puebla, 2 vols. Mexico: Privately printed.

Cervantes, Juan and Patricia M. Fournier. 1995. "El complejo Azteca III Temprano de Tlatelolco: consideraciones acerca de sus variantes tipologías en la cuenca de México." In Presencias y encuentros. Investigaciones arqueológicas de salvamento, edited by Dirección de Salvamento Arqueológico, 83-110. México City: Dirección de Salvamento Arqueológico, INAH.

Cervantes, Juan, Patricia M. Fournier, and M. Carballal. 2007. "La cerámica del Posclásico en la cuenca de México." In La producción alfarera en el México antiguo, volumen V: La alfarería en el Posclásico (1200-1521 d.C.), el intercambio culturaly las permanencias, edited by Leticia Merino and Angél García Cook, 277-320. México, City: INAH.

Charlton, Thomas H. 200o. "The Aztecs and their contemporaries: the central and eastern Mexicanhighlands." In The Cambridge history of the native peoples of the Americas, vol. II: Mesoamerican, Part 1, edited by Richard E.W. Adams and Murdo J. MacLeod, 500-557. Cambridge: Cambridge University Press.

Charlton, Thomas H., Deborah L. Nichols, and C. Otis Charlton. 1992. "Aztec craft production and specialization: archaeological evidence from the city-state of Otumba, Mexico." World Archaeology 23: 98-113. 
Charlton, Thomas H., C. Otis Charlton, and Patricia M. Fournier. 2005. "The Basin of Mexico A.D. 1450-1620. Archaeological dimensions." In The Postclassic to Spanishera transition in Mesoamerica. Archaeological perspectives, edited by Susan Kepecs and Rani T. Alexander, 49-63. Albuquerque: University of New Mexico Press.

Charlton, Thomas H., Patricia M. Fournier, and Juan Cervantes. 1995. "La cerámica del periodo Colonial Temprano en Tlatelolco: el caso de la Loza Roja Bruñida." In Presencias y encuentros. Investigaciones arqueológicas de salvamento, edited by Dirección de Salvamento Arqueológico, 135-155. México City: Dirección de Salvamento Arqueológico, INAH.

Charlton, Thomas H., Patricia M. Fournier, and C. Otis Charlton. 2007. "La cerámica del periodo Colonial Temprano en la cuenca de México: permanencia y cambio en la cultura material." In La producción alfarera en el México antiguo. La alfarería en el Posclásico (1200-1521 d.C.), el intercambio cultural y las permanencias, edited by Beatriz L. Merino Carríon and Ángel García Cook, 429-496. México City: INAH.

Deagan, Kathleen A. 1987. Artifacts of the Spanish Colonies of Florida and the Caribbean, 1500-1800, Volume 1: Ceramics, Glassware, and Beads. Michigan: University of Michigan.

Deagan, Kathleen A. and José M. Cruxent. 2002. Columbus's outpost among the Taínos. Spain and America at La Isabela, 1493-1498. New Haven: Yale University Press.

D’Owler, Luis N. and Howard F. Cline. 1973. "Bernardino de Sahagún, 1499-1590." In Handbook of Middle American Indians, Volume 13: Guide to ethnohistorical sources, part 2, edited by Robert Wauchope, 186-206. Austin: University of Texas Press.

Duarte, Carlos. and María L. Fernández. 1980. La cerámica durante la época colonial venezolana. Caracas: Ernesto Armitano Editor.

Fairbanks, Charles H. 1966. "A feldspar-inlaid ceramic type from Spanish colonial sites." American Antiquity 31 (3): 430-432.

Foster, George M. 196o. Culture and conquest: America's Spanish heritage. New York: Viking Fund Publications in Anthropology 27, Wenner Gren Foundation.

Fournier, Patricia M. 1996. "Tendencias de consumo y diferencias socioétnicas en el valle de México. Contraste entre Tlatelolco y la ciudad de México durante los periodos colonial y republicano." In Memoria del primer congreso nacional de arqueología histórica, edited by E. Fernández and S. Gómez, 448-457. México City: Consejo Nacional para la Cultura y las Artes.

Fournier, Patricia M., M. James Blackman, and Ronald L. Bishop. 2007. "Los alfareros Purépecha de la Cuenca de Pátzcuaro: producción, intercambio y consumo de cerámica vidridada durante la época virreinal." In Arqueología y complejidad social, edited by Patricia M. Fournier, Walburga Wiesheu and Thomas H. Charlton, 195221. México City: Instituto Nacional de Antropología e Historia.

Gámez Martínez, Ana P. 2003. "The forgotten potters of Mexico City." In Cerámica y cultura. The story of Spanish and Mexican Mayolica, edited by Robin F. Gavin, Donna P. 
Piercel and Alfonso Pleguezuelo, 227-242. Albuquerque: University of New Mexico Press.

Garraty, Christopher P. 20o6. "Aztec Teotihuacan: political processes at a Postclassic and Early Colonial city-state in the Basin of Mexico." Latin American Antiquity 17 (4): $363-387$.

Goggin, John M. 1960. The Spanish olive jar: an introductory study, University Publications in Anthropology No. 62, Yale University. New Haven: Yale.

Goggin, John M. 1968. Spanish majolica in the New World: types of the sixteenth to eighteenth centuries. New Haven: Department of Anthropology, Yale University.

Gosselain, Olivier P. 200o. "Materializing identities: an African perspective." Journal of Archaeological Method and Theory 7 (3): 187-217.

Hare, Timothy S. and Michael E. Smith. 1996. "A new Postclassic chronology for Yautepec, Morelos." Ancient Mesoamerica 7 (2): 281-297.

Hernández, Carlos, Robert H. Cobean, Alba G. Mastache, and María E. Suárez. 1999. "Un taller de alfareros en la antigua ciudad de Tula." Arqueología 22: 69-88.

Hernández Sánchez, Gilda. 2005. “Vasijas para ceremonia. Iconografía de la cerámica tipo códice del estilo Mixteca-Puebla.” PhD diss., Leiden University.

Hernández Sánchez, Gilda. 2008. "Indigenous pottery after the Spanish conquest of Mexico: potter's reactions to the new colonial society." Leiden Journal of Pottery Studies 24: $5^{-18 .}$

Hernández Sánchez, Gilda. 2012. Ceramics and the Spanish conquest. Response and continuity of Indigenous pottery technology in central Mexico. Leiden: Brill.

Katz, Roberta R. 1977. "The potters and pottery of Tonalá, Jalisco, Mexico: a study in aesthetic anthropology." Unpublished PhD Diss., Columbia University.

Lind, Michael D. 1994. "Cholula and Mixteca polychromes:Two Mixteca-Puebla regional sub-styles." In Mixteca-Puebla. Discoveries and research in Mesoamerican art and archaeology, edited by Henry B. Nicholson and Keber E. Quiñones, 79-99. Culver City: Labyrinthos.

Lister, Florence C. and Robert H. Lister. 1978. "The first Mexican Maiolicas: imported and locally produced." Historical Archaeology 12 (1): 1-24.

Lister, Florence C. and Robert H. Lister. 1982. Sixteenth Century Maiolica pottery in the valley of Mexico. Tucson: University of Arizona Press.

Lister, Florence C. and Robert H. Lister. 1984. "The potter's quarter of colonial Puebla, Mexico." Historical Archaeology 18 (1): 87-102.

Lister, Florence C. and Robert H. Lister. 1987. Andalusian ceramics in Spain and New Spain. Tucson: The University of Arizona Press.

Lockhart, James. 1992. The Nahuas after the Conquest. Stanford: Stanford University Press.

López Cervantes, Gonzalo. 1976. Cerámica colonial en la ciudad de México, Colección Científica No. 38. México City: INAH. 
Mendieta, Jerónimo de. 1980. Historia eclesiástica Indiana. México City: Editorial Porrúa.

Minc, Leah D., Mary G. Hodge and James Blackman. 1994. "Stylistic and spatial variability in Early Aztec ceramics: insights into pre-imperial exchange systems." In Economies and polities in the Aztec realm, edited by Mary G. Hodge and Michael E. Smith, 133-174. Albany: Institute for Mesoamerican Studies.

Noguera, Eduardo. 1954. La cerámica arqueológica de Cholula. México City: Editorial Guaranía.

Novelo, Victoria. ed. 2007. Artesanos, artesanías y arte popular en México. México City: Consejo Nacional para la Cultura y las Artes.

Pleguezuelo, Alfonso. 1999. “Cerámica de Sevilla (1248-1841)." In Cerámica española. Summa Artis XLII, edited by Trinidad Sánchez-Pacheco, 343-386. Madrid: Espasa Calpe.

Rice, Prudence M. 1987. Pottery analysis. A sourcebook. Chicago: The University of Chicago Press.

Rodríguez Alegría, Enrique. 2002. "Food, eating, and objects of power: class stratification and ceramic production and consumption in colonial Mexico." Unpublished PhD diss., University of Chicago.

Rodríguez Alegría, Enrique. 2003. "Indigenous ware or Spanish import? The case of Indígena Ware and approaches to power in colonial Mexico." Latin American Antiquity 14 (1): 67-81.

Roux, Valentine. 2003. "A dynamic systems framework for studying technological change: application to the emergence of the potter's wheel in the southern Levant." Journal of Archaeological Method and Theory 10 (1):1-30.

Rye, Owen S. 1981. Pottery technology: principles and reconstruction. Washington, D.C.: Taraxacum.

Sahagún, Bernardino de. 1961. The Florentine Codex. General history of the things of New Spain, Book 1o, edited and translated by Charles Dibble and Arthur J. Anderson. Santa Fé: The School of American Research.

Sánchez, José M. 1994. El oficio de ollero en Sevilla en el siglo XVI. Sevilla: Diputación Provincial de Sevilla.

Sánchez, José M. 1996. “La cerámica exportada a América en el siglo XVI a través de la documentación del Archivo General de Indias I. Materiales arquitectónicos y contenedores de mercancías." Laboratorio de Arte 9: 125-142.

Sánchez, José M. 1998. “La cerámica exportada a América en el siglo XVI a través de la documentación del Archivo General de Indias (II). Ajuares domésticos y cerámica cultual y laboral." Laboratorio de Arte 11: 121-133.

Sánchez Cortegana, José M. 1994. El oficio de ollero en Sevilla en el siglo XVI. Sevilla: Diputación Provincial de Sevilla. 
Sanders, William T., Jeffrey R. Parsons and Robert S. Santley. 1979. The basin of Mexico: ecological processes in the evolution of a civilization. New York: Academic Press.

Shepard, Anna O. 1948. Plumbate: a Mesoamerican trade ware. Washington, D.C.: Publication No. 573, Carnegie Institution of Washington.

Tolstoy, Paul. 1958. "Surface survey of the northern valley of Mexico: the Classic and Post- Classic periods." Transactions of the American Philosophical Society 48 (5): $1-100$.

Vega, Constanza. 1975. Forma y decoración en las vasijas de tradición azteca. México City: Instituto Nacional de Antropología e Historia.

Whalen, Michael E. and Jeffrey R. Parsons. 1982. "Ceramic markers used for period designations. Appendix I." In Prehispanic settlement patterns in the southern valley of Mexico: The Chalco-Xochimilco regions, Memoirs of the Museum of Anthropology, No. 14, edited by Jeffrey R. Parsons and Michael E. Whalen, 385-459. Ann Arbor: The University of Michigan Press. 